\title{
Effect of hammer peening with tungsten coating on fatigue properties of carbon steel under rotating bending
}

\section{Vliv povrchové úpravy metodou "hammer peening" a povlaku karbidu wolframu}

Kanchidurai. S.

School of civil engineering, SASTRA University, India

E-mail: kanchidurai@civil.sastra.edu

In the present study, we investigated the influence of hammer peening (HP) with tungsten carbide surface coating (WCSC) on high cycle bending fatigue performance of the carbon steel (CS) manufactured as specified in Bureau of Indian Standards BIS 2062 steel. Totally there are twenty-four numbers of specimens cast and tested to investigate fatigue performance. Constantly high cycle bending fatigue load (HBFL) were applied for all specimen, different range of bending stress applied to the specimen and the stress ratio maintained as $R=1$. Investigation results show there is up to 40 percent of the fatigue life improvement possible by the surface treatments to the CS material. From the research to date the corrosion and pitting corrosion can be treated by modifying the surface layer of the metal by treating different peening methods and coating.

\section{INTRODUCTION}

Fatigue is a phenomenon leading to fracture of a material under repetitive stress or cyclic stress below the strength of the material. The limiting stress up to which a material can withstand a specified number of cycles without fatigue failure is termed as fatigue strength of the material. The total number of cycles a material can sustain at a particular stress is called fatigue life of the material. The endurance limit of a material is the maximum stress below which a material can withstand an infinite number of cycles. The various types of fatigue test are an axial stress cyclic test, bending stress cyclic test, torsional stress cyclic test, and combinations of axial, bending and torsion stress cyclic test. In this paper, the test is done by rotating bar bending stress cyclic test [1] with Avery's fatigue testing machine. In this type of machine, the specimen is fixed at one end and free at another end, so that it behaves like a cantilever. The specimen rotates such that the bending stress can be cycled.

Improving fatigue life is most beneficial because all locomotives, structures is getting a failure due to
Tato práce se zabývala vlivem "hammer peeningu" s povlakem karbidu wolframu na odolnost $k$ vysokocyklové ohybové únavě uhlikové oceli typu BIS 2062. Celkově bylo hodnoceno 24 litých zkušebnich těles. Ve všech testech byl použit stejný počet cyklů a stejný pomèr napètí, ale lišilo se aplikované mechanické napětí. Studie potvrdila, že je možné zvýšit životnost materiálu až o 40 procent povrchovou úpravou. Byla zjištěna $i$ spojitost k rovnomérné i bodové korozi.

fatigue loading, hammer peening is a good one to improve the fatigue life reasonably [2]. Improving surface of the materials many methods are followed especially by peening and coating, generally, types of peening categorized by the methodology which is applied, hammer peening (manual or mechanical), shot peening [3], cavitations peening [4], laser peening [5] \& ultrasonic peening [6].

Tungsten carbide coating is done for the fatigue life improvement, as we know tungsten carbide (WC) has high hardness, impact resistance, corrosion resistance and almost stiffer twice then steel, so in this study tungsten carbide coating is used, the application of coating is continuous combustion high- velocity oxy-fuel (HVOF) thermal spray process [7]. The melting point of tungsten carbide coating is relatively higher than steel hence the hardness will be higher, in fatigue loading cases this will produce the longer endurance limits to the member.

Hammer peening, generally hardening the surface of the material will give better performance in strength and durability like corrosion resistance etc. construction of a surface treatment is the possible way to protect against the aggressive environment. HP is best and 
reliable cold working method, it surely gives significant change to the material properties. In this research blunt nosed steel hammer was used, approximately 40blows per minute was given to the specimen. HP was done before applying tungsten coating. Peening inspection performed by naked eye and $3 \mathrm{x}$ hand magnifier glass

Hammer peening is reliable treatment method for fatigue life improvement; tungsten is the high-density material, hence here chosen to improve fatigue life. High-frequency hammer peening (HFHP) is extending the crack initiation, the fatigue strength of HFHP treated specimens was proved at least twice the fatigue strength of the as welded toe condition [8]. Hammering quality will differ when it's treated manual and by automated, due to this process the strain hardening and tribological characteristics is increased $[9,10]$. Also, the surface of the metal by induction of compressive residual stress using actuators provides hardness improvement of the upper surface of layer and reduction of surface roughness up to mirror-like surfaces [11]. Burnishing and hammer peening also provides an improvement of the surface layer, an important factor of failure is the crack initiation by defects so the defects can be controlled by the burnishing $[12,13]$. The tungsten coating will improve the density of the material [14].

Endurance limit and the fatigue corrosion resistance can be surface layer considerably improved by induction of compressive residual stress by hammer or other mechanical machine peening [17-19].

\section{MATERIAL PROPERTIES}

The metal tested grade of E250 specified in IS2062: 2011, the test results are given in Table 1-4.

\section{EXPERIMENTAL INVESTIGATION}

Fatigue testing machines are preliminarily classified by the mode of loadings, namely direct (axial) stress, plane bending, rotating beam, and alternating torsion, combined stress. In this paper, bending fatigue machines are used to evaluate bending stress, complete reversal load is applied for experimentation.

\section{Details of specimen}

$12 \mathrm{~mm}$ diameter BIS2062 specified rolled steel specimen used and $8 \mathrm{~mm}$ diameter maintained at mid portion shows in Figure 1 as plain specimen 12 numbers and Tungsten carbide (WC) coated specimen nearly $1 \mathrm{~mm}$ thickness in the web portion. 12 numbers cast and tested to find endurance limit of the specimen

\section{Details of equipment}

Figure 2 shows the experimental setup of Avery's fatigue testing machine. Double cantilever fatigue testing machine belongs to the class of machine which produces

Tab. 1. Mechanical properties of BIS 2062 Steel / Mechanické vlastnosti oceli BIS 2062

\begin{tabular}{|c|c|c|c|c|c|}
\hline Description & $\begin{array}{c}\text { Ultimate tensile } \\
\text { strength }\end{array}$ & Yield strength & Young's modulus & Melting point & $\begin{array}{c}\text { Thermal } \\
\text { conductivity }\end{array}$ \\
\hline Range & $464 \mathrm{MPa}$ & $249.7 \mathrm{MPa}$ & $272 \mathrm{GPa}$ & $1425-1540^{\circ} \mathrm{C}$ & $54 \mathrm{~W} /(\mathrm{m} \cdot \mathrm{K})$ \\
\hline
\end{tabular}

Tab. 2. Chemical composition of BIS 2062 Steel / Chemické složeni oceli BIS 2062

\begin{tabular}{|c|c|c|c|c|c|c|}
\hline Constituent & Carbon & Manganese & Silicon & Copper & Sulphur & Phosphorus \\
\hline Permissible variation over the specified limit (\%) & $0.02-0.03$ & 0.05 & 0.03 & 0.03 & 0.005 & 0.005 \\
\hline
\end{tabular}

Tab. 3. Mechanical properties of tungsten / Mechanické vlastnosti wolframu

\begin{tabular}{|c|c|c|c|c|c|}
\hline Description & $\begin{array}{c}\text { Ultimate tensile } \\
\text { strength }\end{array}$ & Yield strength & Young's modulus & Melting point & $\begin{array}{c}\text { Thermal } \\
\text { conductivity }\end{array}$ \\
\hline Range & $1510 \mathrm{MPa}$ & $941 \mathrm{MPa}$ & $411 \mathrm{GPa}$ & $2,785-2,830^{\circ} \mathrm{C}$ & $110 \mathrm{~W} /(\mathrm{m} \cdot \mathrm{K})$ \\
\hline
\end{tabular}

Tab. 4. Chemical composition of BIS 8368:2010 Steel / Chemické složení oceli BIS 8368:2010

\begin{tabular}{|c|c|c|c|c|c|c|}
\hline Constituent & Carbon & Manganese & Silicon & Copper & Sulphur & Phosphorus \\
\hline Permissible variation over the specified limit (\%) & 0.0061 & 0.05 & $0.0001-0.005$ & 0.01 & 0.002 & 0.1 \\
\hline
\end{tabular}


alternating bending stresses. The machine consists of $\mathrm{AC}$ induction motor mounted on the rigid housing and has provision for fixing the fatigue specimen on either side of the shaft using collet type fixing. The load is applied through bearing support at a known distance from the gauge diameter of the specimen. Set of weights are supplied to apply the load in intervals. The number counters that each specimen rotates before failure is indicated on digital counters provided for each side. The rotation is picked up by electronic sensor. When the specimen fails, the pan falls down and operates the microswitch to stop counting the cycles to that side

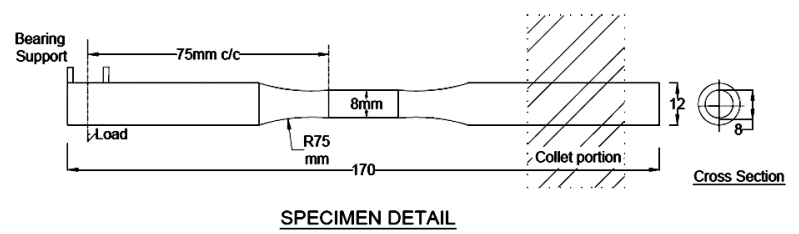

Fig. 1. BIS 2062 Steel Fatigue Specimen

Obr. 1. Vzorek oceli BIS 2062 pro únavovou zkoušku

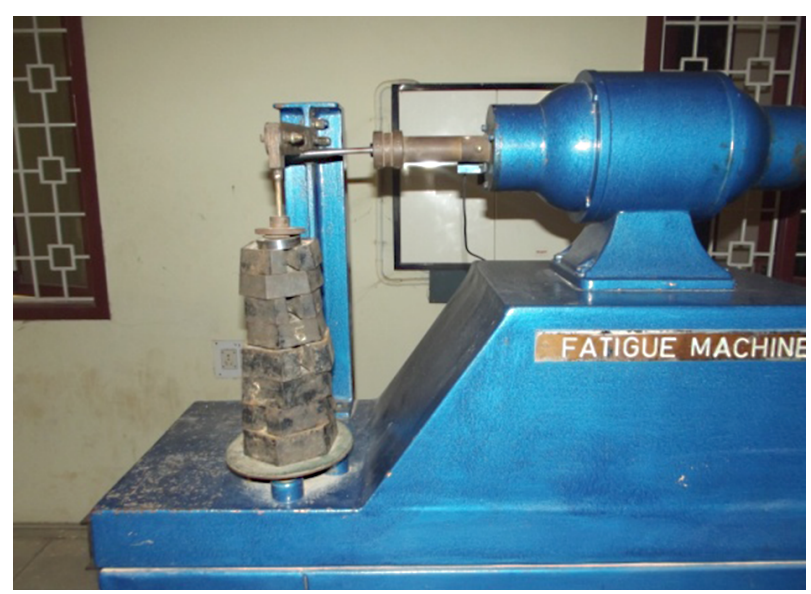

a) testovací nastavení

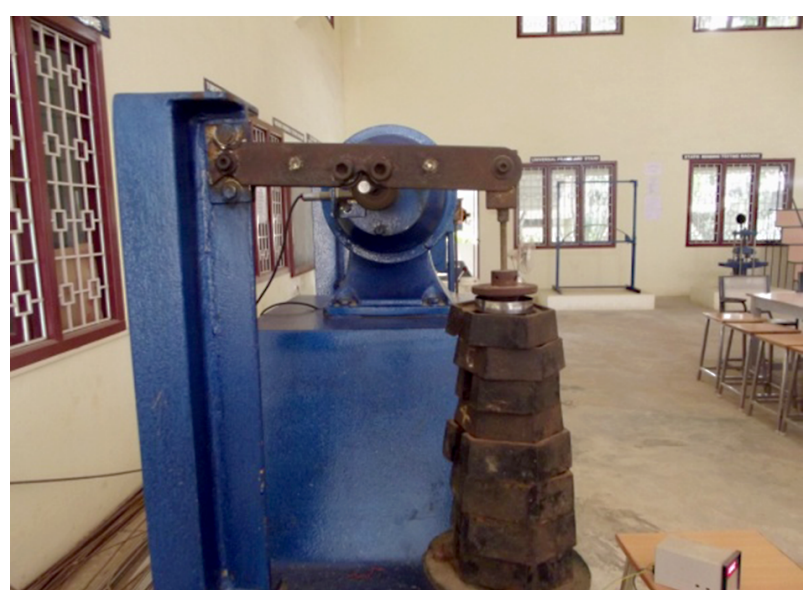

b) uzavřený pohled

Fig. 2. Experimental setup of Avery's fatigue testing machine: a) test set-up, b) closed view

Obr. 2. Experimentální uspořádání únavového testu specimen. The whole equipment is mounted on antivibration mounts for smooth running of the machine.

Horsepower of the motor is $2 \mathrm{HP}, 2800 \mathrm{rpm}$, Electrical power $3 \mathrm{ph}, 10 \mathrm{~A}, 440 \mathrm{~V}$, AC with neutral connection (for digital counter), set of weight for loading $20 \mathrm{Kgs}$, maximum number of counts in $10^{8}$, specimen $12 \mathrm{~mm}$ diameter $\times 170 \mathrm{~mm}$ length with contoured shape at center of diameter $8 \mathrm{~mm}$

\section{RESULTS AND DISCUSSION}

Fatigue life has been predicted based on bending stress Vs Numbers of cycles to failure. initially, standard fatigue specimen tested and it is compared with the specimen which improved the surfaces by hammer peening and tungsten carbide coating.

Bending stress is calculated based on bending theory $(M / I=f / y)$ :

$\mathrm{M}=$ Bending moment, applied force $\times$ perpendicular distance $(75 \mathrm{~mm})$

$\mathrm{I}=$ Section moment of inertia $\pi \mathrm{d}^{4} / 64$

$\mathrm{f}=$ Bending stress

$\mathrm{y}=$ Depth of neutral axis $\mathrm{d} / 2$

Applied force $\mathrm{F}=(2 \mathrm{P}+3) \mathrm{kgf}$, here ' $\mathrm{P}$ ' is extra weight added, High cycle fatigue reversal is applied (2800 rpm). Below tables shows the results of fatigue life of treated and non-treated specimen

From the results, Table 5 shows fatigue life of the carbon steel non-treated BIS2062 steel specimen $8 \mathrm{~mm}$ diameter failure starts when the bending stress raises, if the bending stress level raised appropriately the temperature also increased in the carbon steel specimen, hence the fractured surfaces shows weaker portion and crack initiation in the specimen (Fig. 3a-d).

From the results, Table 5 shows fatigue life of the carbon steel non-treated BIS2062 steel specimen $8 \mathrm{~mm}$ diameter failure starts when the bending stress raises, if the bending stress level raised appropriately the temperature also increased in the carbon steel specimen, hence the fractured surfaces shows weaker portion and crack initiation in the failure specimen Figure 3a, 3b, $3 \mathrm{c}$ and $3 \mathrm{~d}$. Table 5 shows the non treated metal fatigue bending strength and Table 6 shows fatigue life of the carbon steel treated by hammer peening and Tungsten carbide coating has increased bending strength as well as it provides additional resistance against hot spot stress and high cycle fatigue in Figure 4, 5 and 6. Ting Chen et al. clearly mentioned in his research that the corrosion rate considerably reduced and there was a significant improvement in corrosion pitting to treating metal by hammer peening, producing compressive residual stress by HP to the metal makes nano grains and twin nano grains on the surface [16]. 
Tab. 5. Results of non-treated specimen / Výsledky neupravených vzorků

\begin{tabular}{|c|c|c|c|c|c|}
\hline SI. No & Specimen ID & Load in 'N' & Applied load 'N' & Bending stress (MPa) & Numbers of cycles to failure \\
\hline 1 & CS - NT-01 & 60 & 150 & 223.81 & 18170 \\
\hline 2 & CS - NT-02 & 60 & 150 & 223.81 & 19240 \\
\hline 3 & CS - NT-03 & 60 & 150 & 223.81 & 17912 \\
\hline 4 & CS - NT-04 & 80 & 180 & 268.57 & 16002 \\
\hline 5 & CS - NT-05 & 80 & 180 & 268.57 & 15121 \\
\hline 6 & CS - NT-06 & 80 & 180 & 268.57 & 76883 \\
\hline 7 & CS - NT-07 & 120 & 270 & 402.86 & 7671 \\
\hline 8 & CS - NT-08 & 120 & 270 & 402.86 & 7445 \\
\hline 9 & CS - NT-09 & 120 & 270 & 402.86 & 2436 \\
\hline 10 & CS - NT-10 & 200 & 430 & 641.59 & 3279 \\
\hline 11 & CS - NT-11 & 200 & 430 & 641.59 & 2971 \\
\hline 12 & CS - NT-12 & 200 & 430 & 641.59 & \\
\hline
\end{tabular}

Tab. 6. Results of treated specimen / Výsledky vzorků s povrchovou úpravou

\begin{tabular}{|c|c|c|c|c|c|}
\hline SI. No & Specimen ID & Load in 'N' & Applied load 'N' & Bending stress (MPa) & Numbers of cycles to failure \\
\hline 1 & CS - NT-01 & 60 & 150 & 157.19 & 32790 \\
\hline 2 & CS - NT-02 & 60 & 150 & 157.19 & 30170 \\
\hline 3 & CS - NT-03 & 60 & 150 & 157.19 & 34864 \\
\hline 4 & CS - NT-04 & 80 & 180 & 188.62 & 26492 \\
\hline 5 & CS - NT-05 & 80 & 180 & 188.62 & 19967 \\
\hline 6 & CS - NT-06 & 80 & 180 & 282.94 & 11740 \\
\hline 7 & CS - NT-07 & 120 & 270 & 282.94 & 12897 \\
\hline 8 & CS - NT-08 & 120 & 270 & 282.94 & 3915 \\
\hline 9 & CS - NT-09 & 120 & 270 & 450.61 & 4112 \\
\hline 10 & CS - NT-10 & 200 & 430 & 450.61 & 4005 \\
\hline 11 & CS - NT-11 & 200 & 430 & 450.61 & 12165 \\
\hline 12 & CS - NT-12 & 200 & 430 & & \\
\hline
\end{tabular}

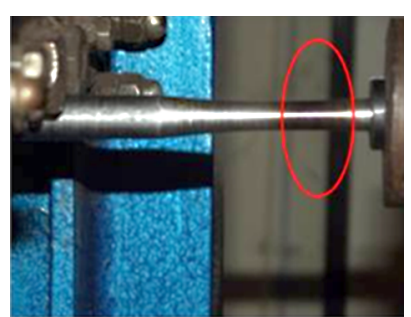

a)

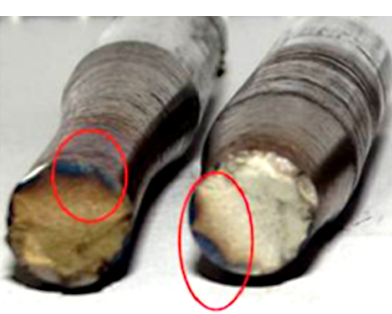

b)

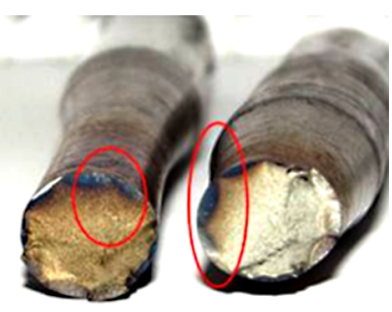

c)

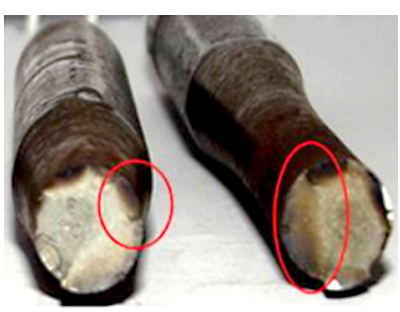

d)

Fig. 3. Fractured surfaces and crack initiation from hot spot Obr. 3. Lomové plochy a iniciační trhlina 


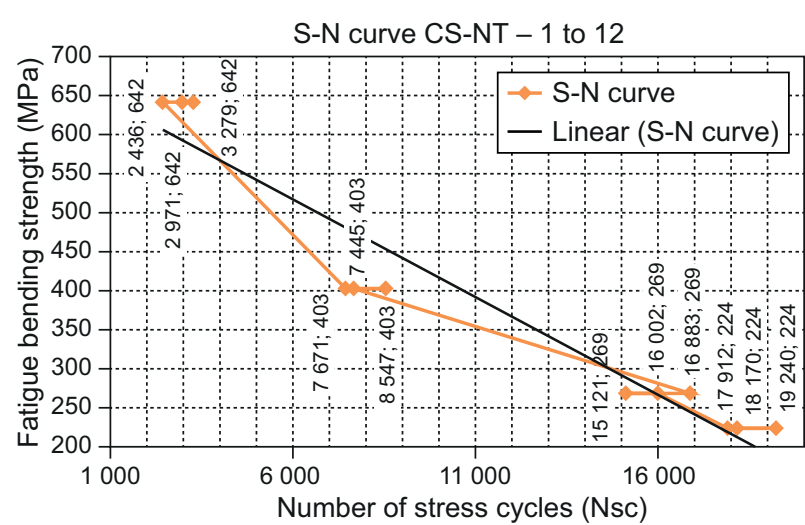

Fig. 4. Endurance limits of the non-treated specimen Obr. 4. Únavová křivka pro neupravené vzorky

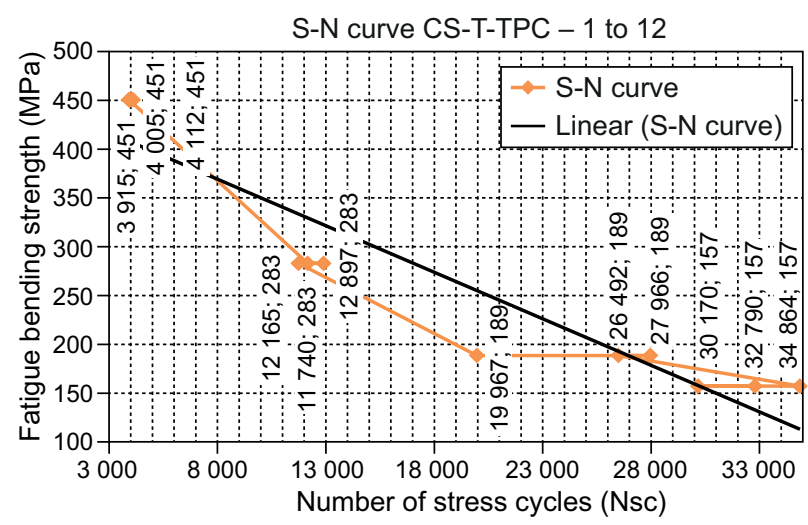

Fig. 5. Endurance limits of the treated specimen Obr. 5. Únavová krívka pro vzorky s povrchovou úpravou

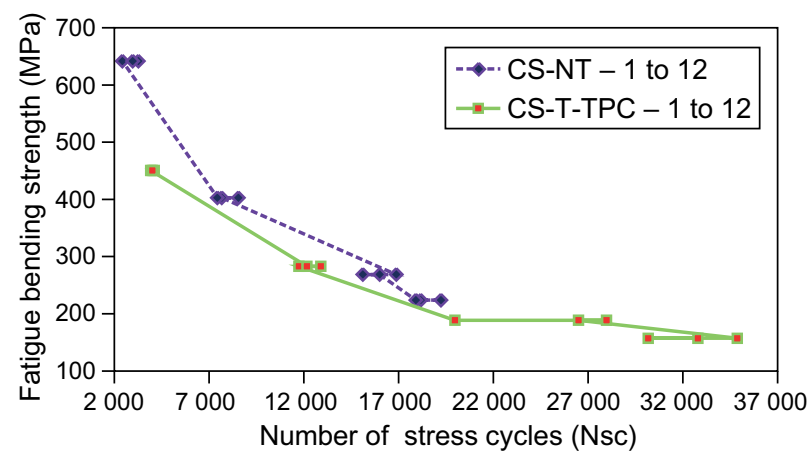

Fig. 6. Endurance limits comparison treated and non-treated specimen

Obr. 6. Porovnání výsledků pro vzorky bez a s povrchovou úpravou

\section{CONCLUSION}

From the experimental results, the surface treated specimen like fatigue and corrosion properties of the metal. The following conclusions were made:

- Use of hammer peening and tungsten carbide coating to the metal was made possible in high strength steel and enhanced the fatigue strength and durability
- Characteristic fatigue strength of metal with HP and WC coating almost attained significant fatigue strength with all twelve numbers of specimen, almost $40 \%$ higher than conventional specimen.

- Metal with WC coating exhibited better resistance against fatigue rotating bending test, among these combination of treatment was found to be optimum in terms of fatigue strength and corrosion resistance.

- It is also conclude that the metal made with hammer peening and tungsten coating performs better.

\section{Acknowledgement}

The authors would like to thank the Vice Chancellor of SASTRA UNIVERSITY for having provided experimental facilities in the School of Civil Engineering to do this research work and also for the continuous support and encouragement given throughout this research work.

\section{REFERENCES}

1. IS 5075-1985. Indian Standard "Method of Rotating Bar Bending Fatigue Testing of Metals", 1985 Reaffirmed 2006.

2. F. Lefebvre and C. Peyrac.: Understanding of fatigue strength improvement of steel structures by hammer peening treatment. Procedia Engineering 2015, 133, 454-464.

3. W.C. Liua and J. Donga: Improvement of fatigue properties by shot peening for $\mathrm{Mg}-10 \mathrm{Gd}-3 \mathrm{Y}$ alloys under different conditions. Materials Science and Engineering A 2011, 528, 5935-5944.

4. H. Soyama and F. Takeo: Comparison between cavitation peening and shot peening for extending the fatigue life of a duralumin plate with a hole. Journal of Materials Processing Technology 2016, 227, 80-87.

5. S. Kikuchi et.al.: Effect of shot peening using ultra-fine particles on fatigue properties of 5056 aluminum alloy under rotating bending. Materials Science and Engineering A 2016, 652, 279-286.

6. D. Yin, D. Wang, H. Jing and L. Huo: The effects of ultrasonic peening treatment on the ultra-long life fatigue behavior of welded joints. Materials and Design 2010, 31, 3299-3307

7. N. A. Ozbek et.al.: Effect of cutting conditions on wear performance of cryogenically treated tungsten carbide inserts in the dry turning of stainless steel. Tribology International 2016, 94, 223-233.

8. J. Berg and N. Stranghoener: Fatigue strength of welded ultra high strength steels improved by high-frequency hammer peening. Procedia Materials Science 2014, 3, 7176.

9. C. Revilla-Gomeza and J-Y. Buffierea: Assessment of the surface hardening effects from hammer peening on high strength steel. Procedia Engineering 2013, 66, 150-160.

10. F. Bleicher et.al.: Improving the tribological characteristics of tool and mould surfaces by machine hammer peening, CIRP Annals - Manufacturing Technology 2013, 62, 239-242. 
11. F. Bleicher et.al.: Mechanism of surface modification using machine hammer peening technology, CIRP Annals - Manufacturing Technology 2012, 61, 375-378.

12. F. Lienerta et.al.: Experimental Study on Comparing Intensities of Burnishing and Machine Hammer Peening Processes. Procedia CIRP 2016, 45, 371-374.

13. V. Schulze et.al.: Surface modification by machine hammer peening and burnishing, CIRP Annals - Manufacturing Technology 2016, 65, 809-832.

14.Z. Lian et.al.: Electrodeposition of tungsten coatings on molybdenum substrates.

15. IS 8368:2010 Indian standard Tungsten Carbide Powder for Hard Metals-Specification.
16. T. Chen et.al. Influence of surface modifications on pitting corrosion behavior of nickel-base alloy 718. Part 1: Effect of machine hammer peening. Corrosion Science 2013, 77, 230-245.

17. M.A.S. Torres, H.J.C. Voorwald, An evaluation of shot peening, residual stress and stress relaxation on the fatigue life of AISI 4340 steel, Int. J. Fatigue 2002, 24, 877-886.

18. K. Liu, M.R. Hill, The effects of laser peening and shot peening on fretting fatigue in $\mathrm{Ti}-6 \mathrm{Al}-4 \mathrm{~V}$ coupons, Tribol. Int. 2009, 42, 1250-1262.

19. I. Weich, T. Ummenhofer, Effects of high frequency peening methods on the surface layers and the fatigue strength of welded details, Mater. Manuf. Process. 2011, 26, 288-293. 